DOI: $10.2478 / \mathrm{v} 10141-009-0025-\mathrm{x}$

\title{
Industrial Heritage Tourism: a Regional Perspective (Warsaw)
}

\author{
Anna Pawlikowska-Piechotka
}

Josef Pilsudski University of Physical Education in Warsaw, Poland

ABSTRACT

When touring a region, one of the things previous generations certainly overlooked were the industrial areas. With the exception of the old saltmine "Wieliczka" in the south of Poland, industrial heritage was mainly unknown. Industrial landscape (mills, factories with chimneys emitting allblackening smoke, poverty-stricken workers' houses) have been regarded with dislike and considered grim.

Using the example of Warsaw's industrial heritage revitalization projects, we examined already modernized historic buildings, which sought to respond to tourist and leisure needs (museums, art galleries, cultural centres). We were interested in their new functions and meanings for urban space quality. We wanted to consider how much revitalized architecture help to change (socially, culturally, economically) declining areas and their painful "inner-city" image (Thorns 2001). Our research (carried out in 2005-2006) covered nine historic industrial compounds, already converted and having new functions. Results of our inquiry polls (taken in 2005-2006) confirmed the thesis, that revitalized historic industrial architecture might enrich urban space with values visible in many dimensions: social, historical, aesthetical and economic (Evans 2005). Although selected and studied cases in Warsaw were not completed equally successfully, due to the objective barriers or carelessness in the planning process, all show good results in space quality and cultural services improvement, appreciated by the local community members and visitors relevantly.

Once neglected run-down Warsaw districts (Wola, Praga) now draw benefits from new identities, attracting tourists and enhancing the local community's sense of belonging and well-being. Similar cases were described by scholars after studies in other European cities (Jones 2006).

KEYWORDS industrial heritage, urban space quality, tourism

\section{Introduction: the meaning of industrial heritage in cultural tourism development}

Tourism is a great opportunity and alternative for areas in decline; it can provide them with a source of economic activity with enormous potential for social and business development and job creation. The regeneration of areas in decline can and should bring about better prospects and improve quality of life (EESC 2005). 
When touring a region, one of the things previous generations certainly overlooked were the industrial areas. With the exception of the old salt-mine "Wieliczka", industrial heritage was mainly unknown in Poland. Moreover, industrial landscape (mills, factories with chimneys emitting allblackening smoke, poverty-stricken workers' houses) have been regarded with dislike and considered grim.

But industrial tourism has become increasingly popular in recent years. Attitudes towards industrial history have changed during the last two decades and industrial civilization has become something to conjure up - in many terms woven into spatial policy issues and research demands: regeneration of devastated areas, conservation, and tourism development. Now tourists in Poland are fascinated and often awestruck by the monumental sights of 19th-century Silesian mines, Łódz cotton mills and Warsaw's historic public services infrastructure. Growing awareness of the Polish industrial history together with tourists' observed willingness to visit ancient water-plants, mills, ironwork plants, old public services buildings - are all clear examples that industrial heritage is regarded by contemporary tourists as being just attractive as Medievels cathedrals. These changes also affected the social environment and are important for the local community, as most of what is today protected or celebrated as industrial heritage had been considered not so long ago as an ugly and even shameful part of the city space.

In Poland visible changes in industrial structure (ownership, organization, branch structure, spatial structure and size of plants) have been observed since 1990. These changes were initiated to meet new economic requirements and to shape efficient model of industrial branches. As a result of the deindustrialization process, many plants, due to the collapse of traditional heavy industry, have been closed. Among many negative consequences we can see large urban areas stunned in decline, job losses, general impoverishment, demographic changes (depopulation). In Poland built-up and disused post-industrial areas make up thousands of hectares, mainly in the Silesia Region. The process of new land use and also adaptating projects of historical structures into new functions, have been carried out, resulting in many transformation projects of industrial premises (Misztal 1998, Niezabitowska 2005). The first urban regeneration projects, implementing new values to the post-industrial compounds, have already been completed in many cities of strong, dominating industrial function in the past (Silesia Region, Łódz). Interestingly, so far these projects were mostly aimed to meet the growing needs of the local community, such as culture, education and leisure, and rarely became an arena of purely commercial investments activities (Nappi-Choulet 2006). Industrial heritage is recognized in many parts of Poland as a significant part of national heritage and as such achieves a remarkable level of interest among visitors. Many urban communities are beginning to realize the potential for developing industry-based heritage tourism (Niezabitowska 2005, Wowrzeczka 2005).

Could tourism development provide Warsaw and its citizens with alternative means for creating new socio-cultural activities and help alleviate the bitter effects of decline by developing new space quality? Does industrial heritage tourism have a long-term future? This paper argues (on the base of case study in Warsaw) that, with careful planning, and realistic, not overoptimistic expectations, there is a chance for a positive role for new tourism options for sustainable transformation areas in decline.

\section{Developing industrial heritage tourism: Context of a case study in Warsaw (2005-2006) and its first results}

One of the contemporary urban planning policy assumptions in Warsaw is an idea to procure a new town environment quality on a basis which rejects distinguishing between the "better, decent" and 
"worse, poor" town districts (Warsaw Spatial Master Plan 2006). It is a revolutionary approach, as for centuries, traditionally in Polish towns the "industrial" districts were recognized in many cases as "not respectful" (ugly, dirty, chaotically planned, dangerous for the local community) and as such not deserving the necessary care, further investment or any improvements.

Today these districts are very often being "re-discovered" and treated as a "new chance" for town development by local community members, tourists, city authorities and planners (PawlikowskaPiechotka 1999). As a consequence, now there is a need to propose and create for Warsaw's postindustrial areas new forms and functions of urban space, which can answer the contemporary society's expectations and aspirations. These designs must very often seek possibilities to resolve the different wishes of future users, problems of construction costs and quality of good architecture, building regulations normative and conservatory requirements. The latter is very important as the very special attention must be paid to these post-industrial landscapes which have historic values. Recognized as a significant part of the national heritage, closed factories, mills and public services buildings can serve for new functions (museum, cultural centre, art gallery) being an attraction for both tourist and local community members.(Davies 1992, Miles 2005, Murphy 2005, Wowrzeczka 2005) A nation unable to recognize its identity, history and tradition would be an alarming thing. Industrial heritage is one of the important aspects of Warsaw's traditional landscape and its heritage's new use has to satisfy local community demand for access.

If we define industrial heritage as "man-made sites, buildings and landscapes that originated with industrial process from the past", then Warsaw can by no means be described as a part of Poland which is rich in a considerably wide range and large numbers of industrial heritage sites (comparing to Silesia) (Misztal 1998, Niezabitowska 1995). Although the industrial tradition of the region reaches the 1st century BC (Pruszków, extraction sites and steel works relics), Warsaw became an "industrialized town" not earlier than in the 19th and 20th centuries (achieving the average industrialization degree, typical for most of the East European cities).

Due to political and technological changes during the past two decades, we have been able to observe in Warsaw, and generally in the whole Mazovia Region, the collapse of many traditional heavy industries and as a result the deterioration of many structures, compounds and even cities (Żyrardów). Government, regional and local authorities are aware that programs of urban renewal are necessary, with a special goal to adapt post-industrial structures of historical value, being protected by law. Actions taken by those have already resulted in the implementation of several projects (Warsaw, Konstancin-Jeziorna, Żyrardów).

In Warsaw there was a tradition of projects dealing with issues concerning post-industrial areas transformation, much older than the process of reconstructing economies into a service-oriented system. One of the earliest projects of conversion, commissioned and completed in the middle of the 1960s, was the old Community Boiler-House, which had been constructed for the WSM Housing Estate in Warsaw in 1930. However successfully it was converted into a cultural centre ("Tęcza Cultural Centre") to serve the local community, unfortunately te project had a very short career. It is a really regretful failure, as finding a new function for this building, designed in modernist style (arch B. Brukalska 1930), was one of the most interesting projects and the "Tecza Cultural Centre" was for a couple of years famous for numerous and highly ambitious "off" theatrical productions and "open" artistic actions, cultural events and workshops.

Much later, in the late 1970s, the old Central Railway Station in Warsaw (constructed about 1931) was converted into the Museum of Railway Network System. It has been serving successfully in this function to this day. This is a rare example of genuine authenticity of a historic site, a great value in the measure of tourist attractions and cultural landscape identity. 
The next conversion was one of the most interesting Warsaw projects of renewing postindustrial heritage into new functions, which was completed in the middle of 1980s. It was an adaptation of the 19th-century Norblin Metallurgic Plant, once located outside the city, but these days already surrounded by numerous housing estates and simply being part of the city centre. One could describe this project as probably the oldest attempt, in our tradition of town planning in Poland, to implement a rehabilitation project through giving new quality to a "brownfield site", formerly devastated industrial area. For more than twenty years a museum and two "off" theatres have been successfully located in the old "Norblin Metallurgic Plant", together with a restaurant and café (Table $1,2)$.

Table 1. Characteristics of selected examples of historic post-industrial buildings in Warsaw (comparison of old and new function in order of conversion chronology)

\begin{tabular}{|c|c|c|c|}
\hline Name & $\begin{array}{c}\text { Date of } \\
\text { construction } \\
\text { Location } \\
\end{array}$ & Original function & New function \\
\hline Old Power Plant & $\begin{array}{c}\text { 1904-1908 } \\
\text { Warsaw }\end{array}$ & $\begin{array}{l}\text { Power Plant for } \\
\text { Municipal Public } \\
\text { Transport } \\
\text { (Tramways) }\end{array}$ & $\begin{array}{c}\text { Museum of } \\
\text { Warsaw's Uprising } \\
\text { (2005) }\end{array}$ \\
\hline Old Paper Mill & $\begin{array}{c}\text { About } 1879 \\
\text { Konstancin-Jeziorna }\end{array}$ & Paper Mill & $\begin{array}{c}\text { Shopping centre } \\
(2004)\end{array}$ \\
\hline $\begin{array}{l}\text { Old Jung's } \\
\text { Brewery }\end{array}$ & $\begin{array}{c}1854 \\
\text { Warsaw }\end{array}$ & $\begin{array}{c}\text { Jung's Brewery in } \\
\text { Warsaw }\end{array}$ & $\begin{array}{c}\text { Numismatic Gallery } \\
\text { (2002) }\end{array}$ \\
\hline $\begin{array}{l}\text { Municipal Water } \\
\text { Plant }\end{array}$ & $\begin{array}{l}\text { About } 1864 \\
\text { Warsaw }\end{array}$ & $\begin{array}{l}\text { Municipal Water } \\
\text { Plant }\end{array}$ & $\begin{array}{c}\text { Museum of City } \\
\text { Infrastructure } \\
(2000)\end{array}$ \\
\hline Old Gas Plant & $\begin{array}{l}\text { About } 1870 \\
\text { Warsaw }\end{array}$ & Gas Plant & $\begin{array}{c}\text { Museum of Gas } \\
\text { Managing } \\
(2000)\end{array}$ \\
\hline $\begin{array}{c}\text { Norblin } \\
\text { Metallurgic Plant }\end{array}$ & $\begin{array}{c}1851 \\
\text { Warsaw }\end{array}$ & Metallurgic Plant & $\begin{array}{c}\text { Museum of Science } \\
\text { and Technology } \\
\text { (1980) }\end{array}$ \\
\hline $\begin{array}{c}\text { Old Main Railway } \\
\text { Station }\end{array}$ & $\begin{array}{c}1931 \\
\text { Warsaw }\end{array}$ & $\begin{array}{l}\text { Main Railway } \\
\text { Station }\end{array}$ & $\begin{array}{c}\text { Museum of } \\
\text { Railways Network } \\
\text { (1970) }\end{array}$ \\
\hline
\end{tabular}

Source: Field studies,II45/ ITiR AWF, Warsaw (2005-2006)

The next post-industrial building converted in Warsaw was a 19th-century Municipal Water Plant. After adaptation in the late 1990s for Warsaw Museum of City Infrastructure, it has served not only as a tourist attraction but, as should be underlined, has still maintained its historical function, being also used for public service as Warsaw Water Plant. About the same time, in the middle of the 1990s, another example of historic municipal infrastructure has been converted into a new function. It was another example of 19th-century municipal infrastructure, the Old Gas Plant, which is used today as Warsaw Museum of Gas Management. Among projects implemented in the years 2000-2005, we can list numerous examples of Warsaw's 19th-century industrial buildings and city municipal plants, adapted for cultural clubs ("CDQ", "Le Madame"), theatres, art galleries ("Otwocka Centre"), shopping canters ("Stara Papiernia"), tea and coffee-shops, restaurants ("Old Jung's Brewery") and museums (Old Warsaw's Mint). As a new attraction we can mention also some abandoned postindustrial buildings designed in the 1950s in the already forgotten "socio-realist" style, which often have a very unique architectural character. These sites are popular now as romantic and unique scenery 
for the theatre performances and rock concerts which are often organized there (for example the famous production of "The Tempest" by Shakespeare in the old Warynski Factory in 2006).

Table 2. Present main function and supplementary functions of selected examples of historic postindustrial buildings in Warsaw

\begin{tabular}{|c|c|c|c|}
\hline $\begin{array}{c}\text { Name } \\
\text { and main function }\end{array}$ & Supplementary function & $\begin{array}{l}\text { Number of } \\
\text { visitors/ } \\
\text { per year }\end{array}$ & $\begin{array}{c}\text { Accessibility: } \\
\text { ticket price/ } \\
\text { barriers for disabled }\end{array}$ \\
\hline $\begin{array}{c}\text { Municipal Transport Power } \\
\text { Plant: } \\
\text { Museum of Warsaw's } \\
\text { Resurrection }\end{array}$ & $\begin{array}{l}\text { Museum, concerts, school } \\
\text { courses, conferences, gift } \\
\text { shops, café }\end{array}$ & 400000 & $\begin{array}{c}\text { Adult admission: } 1 € \\
\text { Facilities for disabled: } \\
\text { toilets, lift services and } \\
\text { runways }\end{array}$ \\
\hline $\begin{array}{c}\text { Paper Mill in Konstancin- } \\
\text { Jeziorna: } \\
\text { Old Paper Mill } \\
\text { Shopping Centre }\end{array}$ & $\begin{array}{l}\text { Shopping centre, art gallery, } \\
\text { cultural centre }\end{array}$ & - & $\begin{array}{l}\text { Adult admission: free } \\
\text { Facilities for disabled: } \\
\text { runways, lift services, } \\
\text { toilets }\end{array}$ \\
\hline $\begin{array}{l}\text { Warsaw's Jung Brewery: } \\
\text { Restaurant "Landa" }\end{array}$ & $\begin{array}{l}\text { Restaurant, museum of } \\
\text { traditional mint technology, } \\
\text { art gallery }\end{array}$ & - & $\begin{array}{l}\text { Adult admission: free } \\
\text { Facilities for disabled: } \\
\text { None }\end{array}$ \\
\hline $\begin{array}{l}\text { Warsaw Museum of City } \\
\text { Infrastructure }\end{array}$ & City Water Plant & 2000 & $\begin{array}{c}\text { Adult admission: } 2 € \\
\text { Facilities for disabled: } \\
\text { None }\end{array}$ \\
\hline $\begin{array}{c}\text { Municipal Gas Plant: } \\
\text { Museum of Gas Managing }\end{array}$ & $\begin{array}{l}\text { Museum, conferences, } \\
\text { seminars, concerts }\end{array}$ & 500 & $\begin{array}{l}\text { Adult admission: free } \\
\text { Facilities for disabled: } \\
\text { None }\end{array}$ \\
\hline $\begin{array}{c}\text { Norblin Metallurgic Plant: } \\
\text { Museum of Science and } \\
\text { Technology }\end{array}$ & $\begin{array}{l}\text { Museum, } 2 \text { "off" theatres, } \\
\text { concerts, art gallery, café }\end{array}$ & 22440 & $\begin{array}{l}\text { Adult admission: } 2 € \\
\text { Facilities for disabled: } \\
\text { runways, toilets }\end{array}$ \\
\hline $\begin{array}{l}\text { Warsaw Main Railway Station: } \\
\text { Museum of Railways Network }\end{array}$ & $\begin{array}{l}\text { Museum, conferences, } \\
\text { school courses, workshops }\end{array}$ & 23000 & $\begin{array}{c}\text { Adult admission: } 2 € \\
\text { Facilities for disabled: } \\
\text { None }\end{array}$ \\
\hline
\end{tabular}

Source: Field studies,II45/ ITiR AWF, Warsaw (2005-2006)

The project, completed in August 2006, is connected with Second World War history: in the 19th-century Warsaw Power Station the Museum of Warsaw's Uprising (1944) has been installed (Table 1,2).

Unfortunately recent debates over the Warsaw Master Spatial Plan (2006) revealed that the further governance of the subsequent projects might be difficult. Although formally mainly cultural/education functions are recommended for the revitalized historic industrial compounds, due to the rapid rise of real-estate prices in Warsaw and developers' strong pressure, many investors are interested in the purely commercial projects, neglecting the social-cultural functions these historic buildings might have. Significant is the case of the 19th-century industrial compound in Warsaw ("Koneser Factory"), which is an example of a purely commercial approach to the urban regeneration performance. There are doubts about whether such mono-functional and only free-market-determined urban development might have been a good contribution to shaping a sustainable, competitive city (Evans 2006, Turok 1992).

\section{Research study (2005-2006) and its first results}

The aim of our study (AWF-DS I 24), undertaken in the years 2005-2006, was to identify the 
problems of the new use of industrial heritage with a special interest paid to those structures which have historical value. The survey focused on the new tourist functions of these historic structures and their role for urban environmental renewal.

The nature of the research objective meant that several different approaches were required. Finally our study was based on:

- A literature review;

- More detailed examination of seven case studies to cover a range of different projects and locations (we selected 9 sites out of a total of 10 historical industrial plants converted into new functions in Warsaw); our survey aimed to include: structured interviews with local authorities representatives, managers of converted buildings and questionnaire polls of tourists (visitors);

- Analysis of existing survey data on industrial heritage in Warsaw (spatial and architectural plans): identification and review of a number of initiatives and projects in each of Warsaw's districts, having projects of land-use changes in the post-industrial areas.

As we believed, the successful conversion of industrial heritage projects should be visitorfriendly, physically and economically accessible, also meet the needs of tourists and local community members and market requirements. These questions underpinned our research (Figure 1, 2). All statistical evaluations in this study reflect tendencies in the new use of cultural heritage (function, management, popularity, disabled access) and were based either on data obtained from local authority offices or information found during fieldwork undertaken by graduate students (workshop sessions in the Institute of Tourism and Recreation AWF in Warsaw and field studies in Warsaw), who participated in this study project (2005-2006). All surveyed examples of industrial heritage were located in Warsaw or its surroundings and had already been converted into new (mainly tourist) functions.

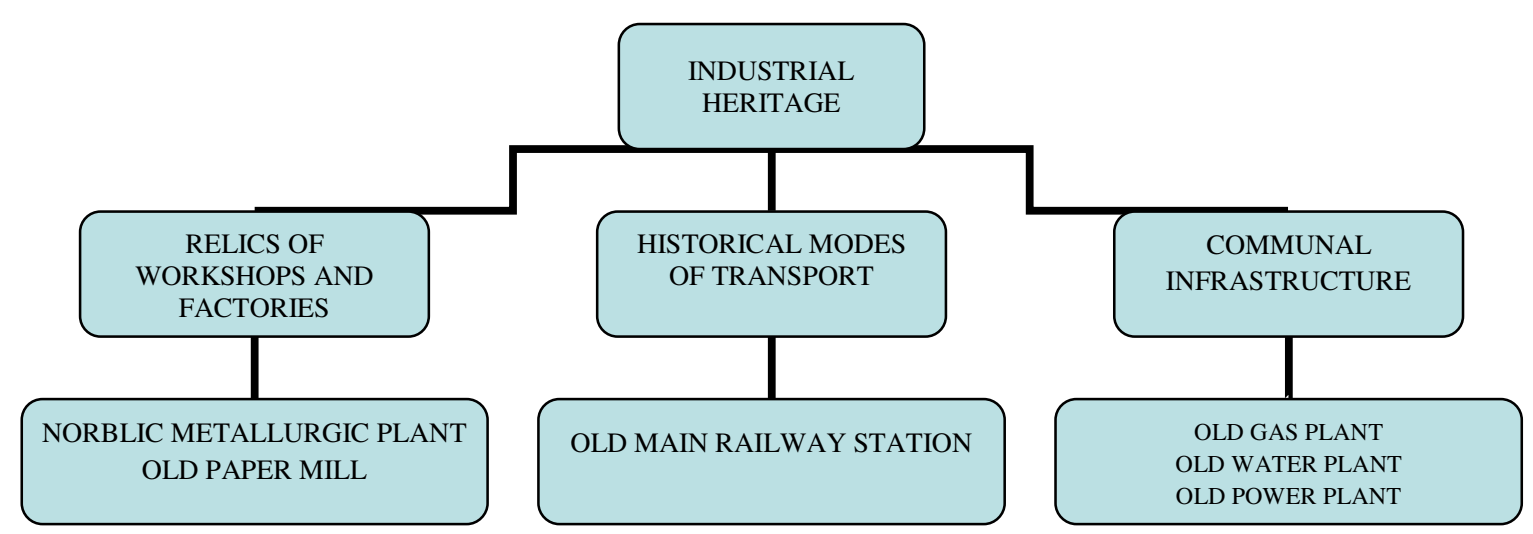

Figure 1. A typology of industrial and communal infrastructure heritage in Warsaw

Source: Field studies,II45/ ITiR AWF, Warsaw (2005-2006)

We were particularly interested in the answers to the following problems:

- historical value of post-industrial building and its primary function

- date of conversion, present owner (management), contemporary main function and cultural activities scheduled

- number of visitors per year, accessibility for disabled 
- future plans for development (and special context: tension between the heritage conservatory office and commercial section)

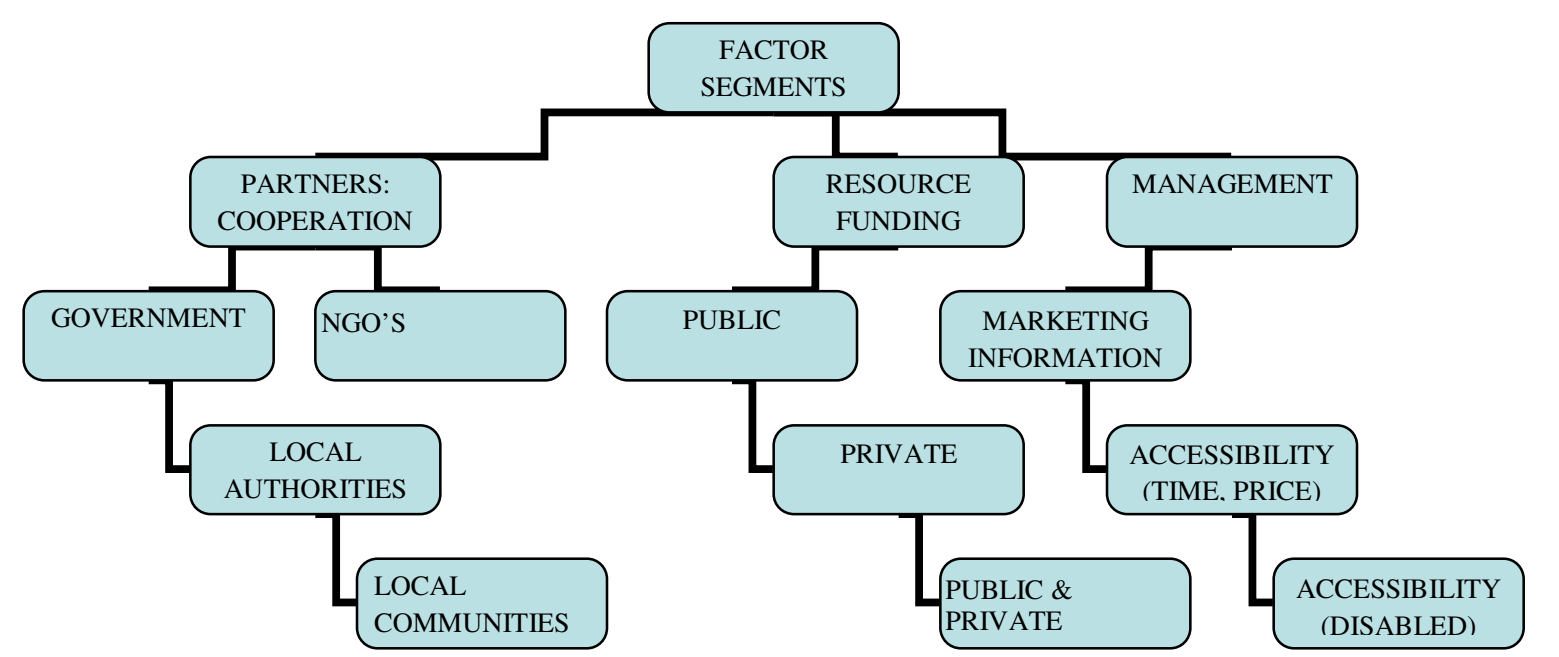

Figure 2. Diagram of the selected factors influencing the post-industrial heritage future possible development

Source: Field studies,II45/ ITiR AWF, Warsaw (2005-2006)

Our questionnaire investigations covered the below-listed sites, and these case studies were chosen with the aim of completing the further and more detailed survey, focusing on the problem of present use of the industrial cultural heritage, its new function and its new meaning for the local community (Table 1, 2):

- Old Jung's Brewery in Warsaw (Art gallery, restaurant)

- Old Gas Plant in Warsaw (Museum of Gas Management)

- Old Main Railway Station in Warsaw (Museum of Railway Network)

- Norblin Metal Plant in Warsaw (Museum of Technology, two theatres, art gallery, cafe and restaurant)

- Old Mint in Warsaw (Museum of Technology, Art Gallery)

- Old Paper Mill in Konstancin-Jeziorna (shopping centre, art gallery, Museum of Paper Technology)

- Old Power Plant in Warsaw (Museum of Warsaw's Uprising)

- Old Textile Factory at Burakowska Street (Cultural Club "CDQ" and art gallery)

- Old Textile Factory in Żyrardów (shopping centre)

Above-listed, selected examples of already implemented rehabilitation projects for postindustrial town "brownfield" sites and attempts to convert historical buildings into new functions, are the proof that the effort on the part of local authorities and planners often constituted significant help to improve the living conditions of local community members. New, society-demanded functions have been created, such as: shops, restaurants, theatres, cultural centres, museums and art galleries. One of the clear signs supporting this statement is the visible popularity of these sites, measured by number of visitors per year. Only in the case of the Museum of Warsaw's Uprising, organized in the old converted Municipal Power Plant, was the number of tourist visitors last year as high as 400,000 (Table 2). 
It is necessary to underline that some of the above-presented examples of historic buildings of past factories or plants were converted thoughtfully, after months of careful architectural studies. Some of the projects have been very highly commended, like for example the Old Paper Mill in Konstancin -Jeziorna, where the design was commissioned by the design group "M.Bulanda, A.Mucha and Associates". It was distinguished by the Association of Polish Architects in 2002 (SARP), due to certain exceptional high-quality achievements such as good function, aesthetic value and outstanding interior arrangement. Moreover, the value of this project can be measured not only as a very unique architectural character which creates a special atmosphere in these sites, not only as reinforcement of crucial functions directed to nearby located housing estates inhabitants (shopping centre, schools), always enthusiastically welcomed by the local community members - but also as a chance for significant cultural activities programs. Both tourists and the local community can enjoy numerous theatre performances, concerts and art exhibitions performed there, and it seems significant that for the most part the cultural program is either free of charge or priced very reasonably. This means that there are no financial barriers to participation in most of these events. Also in this project the crucial problem of disabled accessibility was successfully solved. Unfortunately this question is a painful problem, and most of the historic monuments, due to the conservatory requirements and restrictions, are not easily accessible for the disabled (Table 2).

Reviewing our research material of Warsaw's case studies, we were often astounded when realizing how deeply and intensively the renewal and transformation projects of post-industrial areas had changed the traditional environment, blurring deliberately "ugly and dirty" historic industrial landscape. The consequence of such "total rehabilitation" is a quite different image of landscape. It is less characteristic and the fragments of remaining architectural relics are seldom representative of what was there before. Some of these already-implemented concepts of industrial heritage conversions have resulted in creating structures which never existed, with an attempt to shape "more authentic than realistic" forms of architecture. Although it is true that in many cases visitors are unable to differentiate between "genuine fakes" and authentic industrial heritage, many others (local community members) can recognize the difference and therefore are unable to "witness the past" and feel the identity of the site. In other words, the authenticity is an important attribute of historical landscape and as such should be protected. Attempting to study this question from the broader perspective should be one of the important concerns for Warsaw planners in the future, as industrial heritage should document the place and people who worked in earlier decades in Warsaw's factories and mills.

It is true that implementation of new functions into industrial heritage is a new challenge for Polish urban planners and architects. Deep and broad historical studies concerning industrial heritage have not had a long tradition in Eastern Europe (no more than two decades). Therefore government and local authorities together with architects and urban planners have not got help so far from the academic world. Hopefully architects, historians of art, urban planners, geographers and sociologists who now study industrial culture in Poland will soon produce material, which would obviously serve to better understand heritage resources and become an important help for future projects in Warsaw and other sites. Without such a base, as we fear, it is too easy to overlook the complexity and contradictions of heritage resources, and it is very difficult to consider appropriate new function and form; hard to select suitable technology and building materials for future development (Morozowa 2007, Niezabitowska 1995, Wowrzeczka 2005).

\section{Industrial heritage and cultural tourism: search for authenticity}

It has long been seen that tourists are largely interested in travel which can guarantee authentic experiences and places. The view of cultural heritage authenticity in tourists' searches is often quite 
different from the authenticity understood by historians of art and architecture. Most tour operators and also scholars consider "authenticity" to be one of the most important factors creating the attractions in "tourist space". Mainly they assess the authenticity of cultural and heritage tourism destination sites with the originality and documentation of the past events (Theobald 2004).

Research (Timothy 2003) shows that for the average tourist the value of authenticity is a very important aspect, especially for historic sites, and comprises much of the appeal for visiting certain destinations. On the other hand, this aspect of visitors' satisfaction is somewhat determined by their level of perceptions, and the question of what is authentic and real, from their perception of cultural heritage, is open. Probably the rising level of general education and more sophisticated expectations of tourists will result in the future in deeper need and true desire to visit authentic, natural and "unspoiled" cultural environment.

This applies as a real challenge to projects converting industrial heritage into new functions, since one of the basic attempts on the part of government, local authorities and developers is to change entirely post-industrial areas and structures into a fertile and decent, magnificent environment. Unfortunately the results are astonishingly too aseptic and elegant to be perceived as real and genuine. It may be soon a real problem also in the economic measure, as most of the tour operators agree that recently their clients have started to seek authentic experiences. Therefore growing numbers of tourists who are extremely interested in the authenticity of the sites might feel strongly disappointed if a destination site is not the real industrial landscape showing the impoverishment of the dark capitalism's past (Figure 2).

Because, according to the Polish tour operators' experience, contemporary tourists even want "extra authenticity", this also might mean some danger of changing the historical character of architectural relics to achieve a "better reality" level. These practices, sometimes, to some extent, more or less harmless for cultural heritage (guides with a wink of the eye inventing fairy tales as facts; staged animation events) might became a serious threat to cultural landscape if, for commercial reasons, replicas of structures are sold as reality or very serious changes in the historical environment are implemented - grievously all these reproductions pretend to be and are sold as "real past".

It is necessary to underline that tourists are very prone to such practices, as visitors in most cases are not looking for scientific historical evidence. They are often only partly interested in profound historic studies, and mainly interested in shallow, but impressive experiences. This creates the temptation to provide "genuine fakes", especially if mass market is involved (Pańków 2007).

\section{Conclusions}

Firstly, the rough results of our research (taken in 2005-2006), confirmed the thesis that revitalized historic industrial architecture might enrich urban space with value visible in many dimensions: social, historical, aesthetical, economic; and these changes are widely approved. Although selected and studied cases in Warsaw were not completed equally successfully, due to the objective barriers or carelessness in the planning process, all show good results in space quality and cultural services improvement, appreciated by the local community members and visitors respectively. Onceneglected run-down Warsaw districts (Wola, Praga) now draw the benefits of new identities, attracting tourists and enhancing the local community's sense of belonging and well-being. Similar cases were described by scholars after studies in other European cities (Timothy 2005).

One might be positive about the fact that the significant potential resources for tourist development are deposited by Warsaw's past industrial civilization. The important question is how this 
can be better identified and exploited (with care for historical value and authenticity) in future. Without doubt, a successful project should consider special cultural values before specifying its future tourist function. Later, heritage managers should be concerned with determining appropriate kinds and levels of use, as their main objective is to enrich the cultural resources - not oriented only to gain commercial benefits (Davies 1992, Morozowa 2006, Nappi-Choulet 2006, Turok 1992).

What is visibly missing in some of the reviewed projects is a quality of authenticity. One should be certainly aware that some changes are inevitable, due to the new-functions, building law requirements, new building technologies and materials. Unfortunately, the material of our research shows that in some cases the process of transforming the industrial heritage into a new function (cultural, commercial, public services, education, office) results in an unrecognizable form, very different from the past appearance and character. Regretfully, some designers treat the post-industrial environment simply as a "row material" for the new functions.

Although it is probably never possible to get optimum level in shaping the industrial cultural heritage for tourist functions, it seems that the following principles could be mentioned as the desired policy direction of coherent environment management:

- environmental question: important attempt at rehabilitating the devastated post-industrial area and revitalizating town "brownfield" sites, converting them into new functions and providing new meanings for local community members

- special events, cultural activities, school workshops as an important part of cultural/education program, helping to enhance local (regional) identity

- tourism promotion (seen as a part of commercial networks to support costs of reconstruction and later management and maintenance of historic buildings)

The outcome of good management is sustainable environment creation: for both visitors (tourists) and for the local community. It is necessary to underline that the industrial heritage displayed to tourists is also the heritage of the local people, a symbol of their identity. It is important to enable them to have an effective voice in how the site is managed and to receive benefits from sharing it with visitors (EESC 2005, Evans 2005). Therefore, the local community's more effective participation in industrial heritage reconstruction and rehabilitation projects, seems to be another important task to be taken forward. It is obvious that local people should be at the heart of such a process, among the most important participants of the project. In other words, community involvement in all planning stages (first presentations, later involving several discussions with local authorities and planners) is essential (Hemphril 2004, Thorns,2001, Turok 1992). Simply they are the future beneficiary of social, cultural and physical changes carried out in the industrial heritage areas in their neighbourhoods. Furthermore, without their support, any terms of sustainable, balanced development could not be achieved.

A SWOT analysis revealed a strong demand and expectation showed for this type of industrial heritage use (from the part of polled tourists and local community members). Although strengths were (in 2005) greater than weaknesses, still there were some threats noticeable over the opportunities for this sector of city development, which should be considered in the future urban spatial planning policy (Table 3). We are convinced that there is a need for multilevel cooperation between parts: both external (Town Municipality decisions) and internal (industrial heritage management) to overcome problems and possible traps. Despite the remarkable popularity of renewed industrial sites, there are serious challenges facing the sector of post-industrial areas revival process, and Warsaw sites like the Old Power Plant, Old Paper Mill, Old Water Plant, "Norblin Metallurgic Plant, Old Gas Plant and others, must deal with the reality of peripheral locations, trouble with funding, problems of conservation plan requirements (issued on the basis of uniqueness and important aspect of city heritage). 
Table 3. SWOT analysis results for the industrial heritage tourism sector in Warsaw

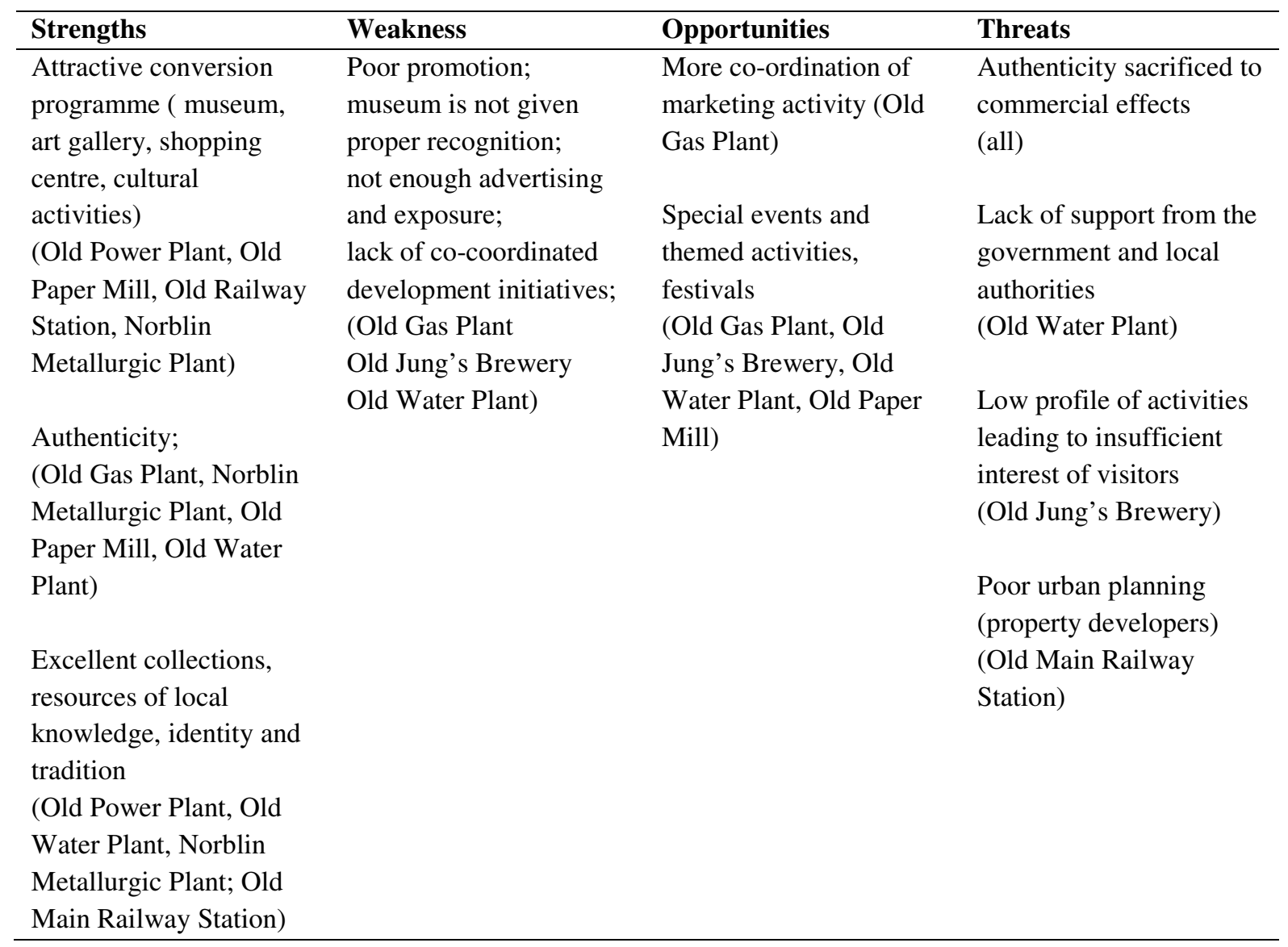

Source: Field studies,II45/ ITiR AWF, Warsaw (2005-2006)

We could treat the below-presented results only as our pilot survey, being aware that the world of industrial heritage, tourism and regeneration of urban areas is very sensitive and that each case is unique. The culture and educative activities (museums, cultural centres), business-oriented services (gift shops, art galleries) - all developed in the post-industrial heritage or disused historic communal infrastructure are a multifaceted problem. In this first stage of our study we intended to depict roughly the present state of the tourist function of the industrial heritage in the Mazovia Region. In the next stage of our survey we plan to focus on other selected issues (types of heritage attractions, management of industrial heritage, tourist demands and comments, local community participation). We are convinced that there may be a need to take a wider, more considered view of industrial heritage and probably the longer-term observations of social changes within tourist groups and local community members.

\section{REFERENCES}

Davies, P. (1992). Managing heritage and tourism projects - a comparative view. Managing Tourism in Historic Cities, Cracow pp. 123-132.

European Economic and Social Committee (2005). The contribution of tourism to the socio-economic recovery of areas in decline (Declaration of Cordoba), Brussels.

Evans, R., Marvin, S. (2006). Researching the sustainable city: three models of interdisciplinary. Environment and Planning A, (38), pp. 1009-1028.

Evans, G. (2005). Measure for Measure: Evaluating the Evidence of Culture's Contribution to Regeneration. Urban Studies, 42 (5/6), pp. 959-983. 
Hemphill, L., Berry, J., McGreal, S. (2004). An Indicator-based Approach to Measuring Sustainable Urban Regeneration Performance: Part 1, Conceptual Foundations and Methodical Framework. Urban Studies, 41 (4) pp. 725-755.

Hemphill, L., Berry J., McGreal, S. (2004). An Indicator-based Approach to Measuring Sustainable Urban Regeneration Performance: Part 2, Empirical Evaluation and Case-study Analysis. Urban Studies, 41 (4) pp. 757-772.

Jones, P., Evans, J. (2006). Urban Regeneration, Governance and the State: Exploring Nations of Distance and Proximity. Urban Studies, 43(9), pp. 1492-1507.

Leslie, D. (2006). Sustainability and environment management. International Cultural Tourism. Oxford, pp. 111-121.

Miles, S. (2005). "Our Tyne": Iconic Regeneration and Revitalization of Identity in NewcastleGateshead. Urban Studies, 42 (5/6), pp. 913-926.

Misztal, S. (1998). Warsaw Industrial Structure Transformation. Warsaw: PAN IGiPZ, pp. 129-130.

Murphy, P.E., Price, G. (2005). Tourism and Sustainable Development. Global Tourism, Oxford pp. 167-193.

Morozowa, J. (2006). Industrial Architecture Archivolta. Crocow, pp. 68-70.

Nappi-Choulet, I. (2006). The Role and Behavior of Commercial Property Investors and Developers in French Urban Regeneration: The Experience of the Paris Region. Urban Studies, 43 (9) pp. 1511-1535.

Niezabitowska, E. (1995). Industrial Relics and Restructuring. Zeszyty Naukowe Politechniki Śląskiej Architektura, 25 (1263) pp. 11-17.

Pańków, J. (2007). Resurection in the pop-version. Wysokie Obcasy, 32/2007, pp. 34-36.

Pawlikowska-Piechotka, A. (1999). Industrial Heritage on the Real Estate Market. Real Estate Management, Warsaw, pp. 160-175.

Timothy, D.J. (2003). Heritage Tourism. Oxford, pp. 88-92.

Thorns, D.C. (2001). The Transformation of Cities (Urban Theory and Urban Life). Macmillan: London.

Turok, I. (1992). Property-led urban regeneration: panacea or placebo? Environment and Planning A, 24, pp. 361-379.

Warsaw Spatial Master Plan (2006). Warsaw City of Warsaw Municipality.

Wowrzeczka, B. (2005). The Transformation of Postindustrial Areas as a Chance for Sustained Development of City Environment, Aspects of Equilibrium, Wrocław, pp. 513-517. 